logos_i_ethos_2020_(52), s. 5-8

DOI: http://dx.doi.org/10.15633//lie.3574

\title{
Narracje o technoewolucji - nowe technologie i nowy człowiek?
}

Rozwój techniki i nowych technologii wpływa na zmianę najbliższego otoczenia człowieka, zmienia jego obyczaje, nawyki, sposoby komunikowania się, postrzeganie przyszłości, rozumienie tego, co prywatne i publiczne. Historia ludzkości opisywana przez antropologów kulturowych od najwcześniejszych, przedpiśmiennych czasów wskazuje na użytkowanie narzędzi technicznych. Narzędzi używano do polowań, uprawnia ziemi, w rzemiośle, posługiwano się nimi do walki o władzę, obrony przed agresorem lub dzikimi zwierzętami. Wizja rozwoju techniki ukształtowała nasze postrzeganie historii człowieka - epoka kamienna, epoka brązu, żelaza, stali... Współczesność określa się czasem epoką nowych technologii, rzeczywistości cyfrowej, epoką Przemysłu 4.o; te określenia wpisują się w „czwarty” etap rewolucji przemysłowej.

Maszyny od zawsze były przedmiotem z jednej strony fascynacji, a $\mathrm{z}$ drugiej rozczarowania. $\mathrm{W}$ kulturze odnajdujemy ślady fascynacji wytworami techniki z przełomu XIX i XX wieku, widoczne między innymi w prozie i poezji tamtego okresu. Jednocześnie rozwój techniki wiązał się z wytworzeniem narzędzi masowej zagłady, które pozwoliły jednym ludziom w sposób mechaniczny i zwielokrotniony odbierać życie innym ludziom. Wówczas fałszywa okazała się teza, że narzędzia techniczne są neutralne aksjologicznie, wszak niektóre $\mathrm{z}$ nich stworzono specjalnie do odbierania życia ludziom lub zwierzętom. W ostatnim czasie wyraźnie uświadomiliśmy sobie, że działalność człowieka wpływa na zmiany w środowisku naturalnym, możliwe, że w nieodwracalny 
sposób. Obecnie nie wystarczy już nie niszczyć środowiska, ale należy je chronić, robimy to między innymi używając narzędzi technicznych.

Współcześnie możemy zauważyć kolejne etapy fascynacji techniką. Narzędzia ułatwiają nam komunikację z innymi, umożliwiają pozyskiwanie i przetwarzanie informacji na niebywałym poziomie, zapewniają rozrywkę. Do nowinek technicznych z czasem się przyzwyczajamy, oczywiście ludzie młodzi szybciej niż starsi (np. telefon komórkowy, smartfon). Nowoczesne społeczeństwa związały się z technikami informatycznymi tak silnie, że nie mogą już w zasadzie bez nich funkcjonować. Obserwowane przez nas zmiany technologiczne i powiązane z nimi zmiany cywilizacyjne zmuszają do pytań o diagnozę obecnego stanu relacji człowiek - maszyna oraz perspektywę tej relacji w przyszłości.

Wydaje się, że poważnym wyzwaniem jest również wprowadzenie wytworów techniki w obręb naszego ciała, czyli cyborgizacja człowieka. Dzieje się to jednak nie tylko w ramach tradycyjnie pojętej medycyny, która posługuje się coraz bardziej wyrafinowanymi implantami. Może się to stać $\mathrm{z}$ powodów wynikających $\mathrm{z}$ naturalnych ludzkich pragnień, czyli z troski o zachowanie lub poprawę jakości życia. Chcemy zachować sprawność ciała i umysłu w jak najdłuższym okresie życia, ale także pragniemy wiedzieć więcej, czuć wyraźniej, biegać szybciej itp. Techniczne możliwości ulepszania cielesnej i kognitywnej strony człowieka skłaniają do postawienia na nowo pytań o stosunek tego, co naturalne i sztuczne, w kontekście zmian, które będą dotyczyć naszego najbliższego środowiska i kondycji naszych ciał.

Niebywałe nasycenie otoczenia zaawansowanymi technologiami domaga się podjęcia refleksji filozoficznej nad zmianami w otaczającej nas rzeczywistości. Mamy jednak świadomość, że w konfrontacji z tą nową i niezwykle złożoną problematyką musimy filozoficzne pytania stawiać $\mathrm{w}$ perspektywie interdyscyplinarnej. To właśnie dzięki zderzeniu różnych punktów widzenia możemy łatwiej i bardziej precyzyjnie dostrzec nowe problemy i nowe wyzwania, jakie przynoszą nam obecne wśród nas zaawansowane techniki. Niniejszy numer czasopisma „Logos i Ethos" chcemy więc poświęcić analizie współczesnych odsłon relacji człowiek - maszyna - nowe technologie. Zaproszeni przez nas autorzy 
omawiają różne aspekty wpływu współczesnej techniki na ludzi z punktu widzenia filozofii człowieka, filozofii techniki, teologii, kulturoznawstwa i literaturoznawstwa.

Tytuł niniejszego zbioru Narracje o technoewolucji - nowe technologie i nowy człowiek? nie jest stwierdzeniem, pragniemy raczej, aby zawarte w nim pytanie stało się zaproszeniem do namysłu nad kwestią wpływu współczesnej techniki na ludzkie życie.

W pierwszej części znajdują się teksty poświęcone zagadnieniu cyborgizacji człowieka. Mariusz Wojewoda pisze o trzech modelach narracji na temat techniki, które funkcjonują we współczesnym dyskursie naukowym i pozanaukowym. Szczególnie omawia napięcie między narracją inżyniersko-pragmatyczną i humanistyczno-kulturową. Jak na razie, oba te modele pozostają w konflikcie, brakuje koncepcji, która mogłaby pogodzić obie perspektywy. Paweł Polak i Roman Krzanowski piszą o możliwości stworzenia fronetycznych robotów, urządzeń, które mogłyby bezpiecznie towarzyszyć nam w pracy i wykonywaniu codziennych czynności, przyjaznych i usłużnych wobec człowieka. Krzysztof Wieczorek analizuje dwie kategorie pozwalające wytyczyć granicę między człowiekiem a maszyną, czyli kategorię wdzięku i kategorię „potworności”. Rozważa w tym kontekście również kwestię utraty przez nas kontroli nad technoewolucją. Marcin Mazurek przedstawia natomiast współczesną literaturę cyberpunkową, która ujawnia interesujące problemy filozoficzne związane z problematyką cielesności i możliwością informacyjnego sposobu rozumienia duszy ludzkiej jako kodu informacyjnego, który może nas reprezentować po śmierci ciała.

W drugiej części, poświęconej interdyscyplinarnym rozważaniom nad filozoficznym problemem cielesności, Jan Słomka analizuje zagadnienie cielesności w ujęciu Emmanuela Lévinasa w kontekście autentyczności spotkania człowieka z innym człowiekiem. Spotkanie wirtualne nie jest w stanie zastąpić tego wymiaru spotkania, szczególnie, gdy chodzi o pieszczotę i rozkosz erotyczną ujawniającą, jak ważne jest ucieleśnienie człowieka. Urszula Żydek-Bednarczuk przedstawia problem ciała i cielesności w kontekście współczesnej kultury medialnej, strategii reklamowych i kontaktów międzyludzkich za pośrednictwem mediów 
społecznościowych, wskazując na dokonujące się w tej sferze transformacje rozumienia cielesności. Marek Wójtowicz analizuje kwestię poszukiwania nowych form nieśmiertelności w cyberświecie i wskazuje na zagrożenia $\mathrm{z}$ tym związane. Anna Maliszewska $\mathrm{z}$ punktu widzenia teologii omawia różne sposoby podejścia do ciała, w kontekście aprobowanej współcześnie formuły śmierci mózgowej. Zestawia medyczną koncepcję śmierci mózgowej z chrześcijańskim rozumieniem człowieka będącym przedmiotem tradycyjnych ujęć filozofii chrześcijańskiej.

Wszystkie teksty stanowią niejako kolejne odsłony współczesnego postrzegania relacji człowiek-maszyna, szans, zagrożeń i wyzwań związanych z wykorzystaniem narzędzi technicznych do utrzymania i poprawy jakości życia. Wskazują one na problem określenia granic takiej ingerencji i na zmieniający się zakres odpowiedzialności za ludzkie wybory dotyczące wytworów techniki. Mamy nadzieję, że ukazana tu mozaika problemów i podejść będzie zachętą do dalszego zgłębiania problemów filozoficznych, które stawia przed nami niebywały rozwój nowoczesnej techniki.

Paweł Polak

Mariusz Wojewoda 